\title{
PENGEMBANGAN VIRTUAL LABORATORY BERBASIS MULTIMEDIA INTERAKTIF PADA MATA KULIAH MICROBIOLOGY SUB MATERI ISOLASI BAKTERI
}

\author{
Laili Fitri Yeni, Yokhebed \\ Program Studi Pendidikan Biologi FKIP Untan \\ Lailifitri74@gmail.com
}

\begin{abstract}
This research aims to produce Virtual Laboratory as interactive multimedia on sub material the isolation of bacteria, knowing about adisability of Virtual Laboratory, and measure the comprehension of the student PGMIPAU Education Biology FKIP Untan concept whom get be taught with Virtual Laboratory. The research method that used is a Development Research. This method includes four stages that is the analysis and design stage for produce Virtual Laboratory prototype. The next stage is evaluation and revision until the Virtual Laboratory was proper to use. Implementation of media have done at small group (the student PGMIPAU Education Biology). Be based on result of validation by validator of media and matter, Virtual Laboratory get catagorized as valid with the average of the validation is 3,18 . Be based on result of student learnig outcomes obtained average 75,55 with the percentage of completness is $88,88 \%$.

Keywords: Virtual Laboratory, isolation of bacteria.
\end{abstract}

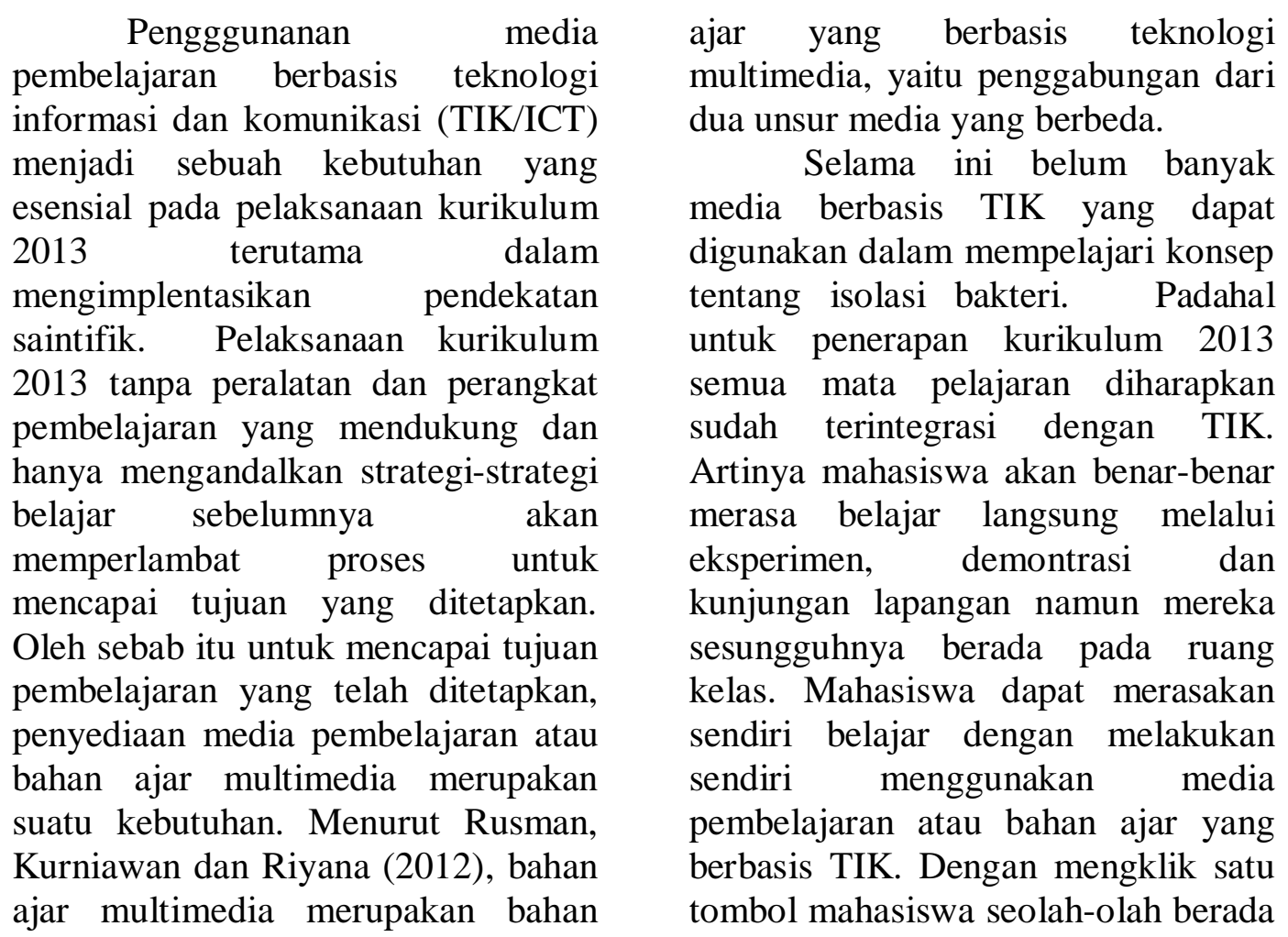


pada dunia nyata. Suasana belajar seperti itu yang dimaksudkan jika TIK terintegrasi pada semua mata pelajaran. Untuk menciptakan suasana seperti itu mutlak dibutuhkan media atau bahan ajar multimedia. Selama ini belum banyak media berbasis TIK yang dapat digunakan dalam mempelajari konsep isolasi bakteri.

Kendala ini yang melatarbelakangi dilakukannya penelitian pengembangan media belajar yaitu virtual laboratory berbasis multimedia interaktif.

Virtual laboratory adalah serangkaian alat-alat laboratorium yang berbentuk perangkat lunak (software) komputer berbasis multimedia interaktif, yang dioperasikan dengan perangkat keras (hardware) komputer dan dapat mensimulasikan kegiatan di laboratorium seakan-akan pengguna berada pada laboratorium sebenarnya (Santoso, 2009). Menurut Oetomo (dalam Razi, 2013), Asyhar (2012), ada beberapa kelebihan yang dapat diperoleh dengan menggunakan virtual laboratory, yaitu: 1) Tidak memerlukan peralatan laboratorium dan bahan-bahan yang harganya mahal, sehingga dapat menjadi alternatif mengatasi keterbatasan atau ketiadaan fasilitas alat dan bahan laboratorium, 2) mengurangi keterbatasan waktu, jika tidak ada cukup waktu untuk mengajari di dalam laboratorium, 3) kemampuan komputer untuk menayangkan kembali informasi yang diperlukan oleh pemakainya (kesabaran komputer) dapat membantu siswa yang memiliki kecepatan belajar lambat (slow learner), 4) lebih interaktif, sehingga peserta didik dapat melakukan praktikum sebagaimana yang dilakukan pada laboratorium fisik dengan visual yang menarik, 5) peserta didik dapat menggunakan secara sendiri-sendiri atau berkelompok dan tidak mesti di ruang laboratorium, 6) meningkatkan keamanan dan keselamatan, karena tidak berinteraksi dengan alat dan bahan kimia yang nyata.

Keunggulan virtual laboratory sebagai media pembelajaran telah banyak diteliti kebermanfaatannya, seperti: 1) Penerapan media virtual laboratory berbasis inkuiri berpengaruh terhadap hasil belajar siswa pada materi pokok kelarutan dan hasil kali kelarutan di SMA Negeri 1 Belik, Pemalang. (Nurrokhmah dan Sunarto, 2013). 2) Penggunaan virtual laboratory sebagai media pembelajaran berbasis komputer pada materi pembiakan virus memberikan respon sangat positif siswa sebesar 83, 8\% (Yuniarti, Dewi, dan Susanti, 2012).

Virtual laboratory yang dibuat dalam penelitian ini adalah pada sub materi isolasi bakteri pada mata kuliah microbiology program PGMIPAU. Mata kuliah microbiology merupakan salah satu mata kuliah yang diajarkan pada mahasiswa PGMIPAU. Untuk mengikuti perkembangan perubahan kurikulum, maka mata kuliah inipun sudah mulai dirancang untuk dapat mengimplementasikan kurikulum 2013, salah satunya dengan menerapkan pendekatan saintifik berbasis TIK. Indikator dari sub materi ini adalah: mahasiswa mampu menjelaskan urutan teknis isolasi bakteri dengan benar, mampu menjelaskan prinsip sterilisasi, isolasi dan teknis aseptis. Pemaparan 
tersebut membuat penelitian ini menarik untuk dilakukan.

Berdasarkan pemaparan di atas maka menjadi menarik untuk mengembangkan virtual laboratory berbasis multimedia interaktif pada sub materi isolasi bakteri dan mengimplementasikan media tersebut pada mahasiswa PGMIPAU Pendidikan Biologi FKIP Untan untuk mengetahui pemahaman konsep mahasiswa pada sub materi isolasi bakteri yang diajarkan dengan menggunakan virtual laboratory berbasis multimedia interaktif.

\section{Metode}

Penelitian ini merupakan tahap awal yang bertujuan untuk mengembangkan virtual laboratory. Penelitian ini menggunakan metode riset pengembangan atau development research (Akker dalam Susanti, 2008). Penelitian ini secara umum terdiri dari dua tahap yaitu preliminari studi (analisis dan desain) dan formatif studi (evaluasi dan revisi). Proses pengembangan meliputi: analisis, desain, evaluasi, dan revisi (Akker dalam Susanti, 2008). Langkah-langkah di atas dapat dijelaskan berikut:

\section{Preliminari studi}

Kegiatan yang dilakukan dalam tahap analisis meliputi: analisis kurikulum, analisis materi (concept analysis) dan perumusan tujuan perkuliahan (specifying instructional objectives). Tahap perancangan (disain) bertujuan untuk merancang media virtual laboratory. Kedua tahap ini bertujuan untuk memperoleh gambaran tentang bentuk dan komponen-komponen yang ditampilkan pada virtual laboratory yang akan dibuat dengan aplikasi macromedia flash sampai dihasilkan prototipe media virtual laboratory.

\section{Formatif studi}

Pada tahap ini meliputi tahap evaluasi dan revisi. Tahap evaluasi prototipe produk dilakukan beberapa tahap yaitu: (1) review ahli media, (2) review ahli materi, (3) uji coba kelompok terbatas. Setelah dilakukan evaluasi melalui proses validasi oleh ahli materi dan ahli media maka dilakukan revisi prototipe sampai dinyatakan valid. Selanjutnya dilakukan uji coba terbatas, dan hasil analisis uji coba terbatas kemudian dianalisis untuk mengetahui keefektifan media virtual laboratory tersebut.

Instrumen yang digunakan dalam pengumpulan data mengenai kelayakan media adalah angket. Angket yang digunakan untuk mengumpulkan data terdiri dari angket untuk ahli media dan angket untuk ahli materi. Angket yang digunakan adalah angket tertutup dengan teknik rating scale. Aspek penilaian meliputi aspek format, bahasa, isi, kepraktisan, dan keefektifan.

Instrumen untuk mengukur pemahaman konsep siswa adalah tes hasil belajar. Subjek penelitian adalah seluruh mahasiswa S1 Reguler ( PGMIPAU) Program Studi Pendidikan Biologi yang mengambil mata kuliah microbiology. Tes dilakukan untuk melihat kemampuan mahasiswa dalam memahami konsep mengenai prosedur teknik isolasi bakteri dalam mata kuliah microbiology. Soal tes berbentuk pilihan ganda berjumlah 10 soal. Sebelum digunakan soal tes divalidasi terlebih dahulu oleh validator sekaligus validasi ahli materi pada 
bagian evaluasi di media virtual laboratory. Validasi yang dilakukan adalah validasi isi, untuk melihat kesesuaian isi materi dengan instrumen atau soal tes. Mahasiswa dikatakan tuntas apabila mendapat nilai $\geq 70$.

\section{Hasil dan Pembahasan}

Hasil pengembangan media virtual laboratory sesuai dengan tahapan pengembangannya sebagai berikut:

\section{A. Analisis}

1. Analisis Kurikulum. Pada tahap ini, dilakukan tinjauan terhadap kurikulum berdasarkan silabus mata kuliah microbiology. Berdasarkan hasil analisis kurikulum maka kompetensi dasar pada mata kuliah microbiology yang dituangkan dalam pembuatan media virtual laboratory ini yaitu mahasiswa dapat melakukan teknik isolasi bakteri melalui simulasi virtual laboratory

2. Analisis materi (concept analysis). Berdasarkan hasil analisis materi maka cakupan materi yang disampaikan melalui media virtual laboratory ini adalah sterilisasi, pemilihan medium, dan isolasi bakteri yang menggunakan teknik seperti pour plate dan streak plate.

3. Perumusan tujuan perkuliahan (specifying instructional objectives). Rumusan tujuan perkuliahan adalah sebagai berikut:
a. Mahasiswa
dapat
menjelaskan
tahapan
sterilisasi alat dan media

melalui visualisasi virtual laboratory.

b. Mahasiswa dapat menentukan dengan tepat alat dan bahan yang digunakan dalam pembuatan media melalui visualisasi virtual laboratory.

c. Mahasiswa dapat mendeskripsikan tahapan isolasi bakteri melalui simulasi virtual laboratory.

d. Mahasiswa dapat membedakan teknik isolasi pour plate dan streak plate melalui simulasi virtual laboratory.

\section{B. Desain}

Tahap ini berisi pendesainan yang dimulai dari sketsa pada gambar pada kertas. Tahap ini bertujuan untuk memperoleh gambaran tentang bentuk dan apa saja yang ditampilkan pada macromedia flash. Desain terdiri dari menu utama dan menu pendukung. Menu utama terdiri dari kompetensi dasar, materi penanaman bakteri yang di dalamnya terdapat menu simulasi dan evaluasi. Sedangkan menu pendukung terdiri dari petunjuk, animasi, profil, dan musik. Selanjutnya dilakukan desain menggunakan komputer dengan program macromedia flash.

Pada tahap desain ini dibuat skrip terlebih dahulu yang merupakan gambaran keseluruhan alur (flow) dari media virtual laboratory yang akan di buat. Alur program dimulai dari start, isi, dan exit. Tahap selanjutnya adalah membuat storyboard. Pada tahap desain ini menghasilkan prototype media virtual laboratory sebagai berikut:

1. Halaman menu terdiri dari menu kompetensi dasar (KD), 
materi penanaman bakteri, dapat dilihat pada Gambar 1. evaluasi, dan petunjuk seperti

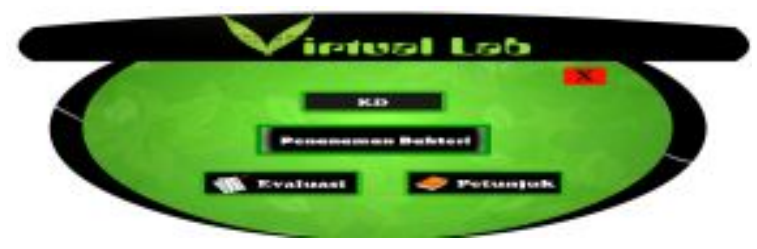

Gambar 1. Tampilan Menu Virtual Laboratory.

Pada halaman menu ini lay out (tampilan) sudah berisi aspek visual seperti gambar, teks, dan warna serta sudah terdapat granularity (ikon-ikon) yang dihubungkan dengan hiperlink terstruktur serta digunakan untuk membagi-bagi text dalam bab dan subbab.

2. Materi Penanaman Bakteri: berisikan sajian materi penanaman bakteri secara singkat (Gambar 2). Berdasarkan Gambar 2, pada halaman ini materi penanaman bakteri ditampilkan secara ringkas tujuannya agar mahasiswa mengetahui secara garis besar cakupan materi yang akan di sampaikan melalui media virtual laboratory ini.

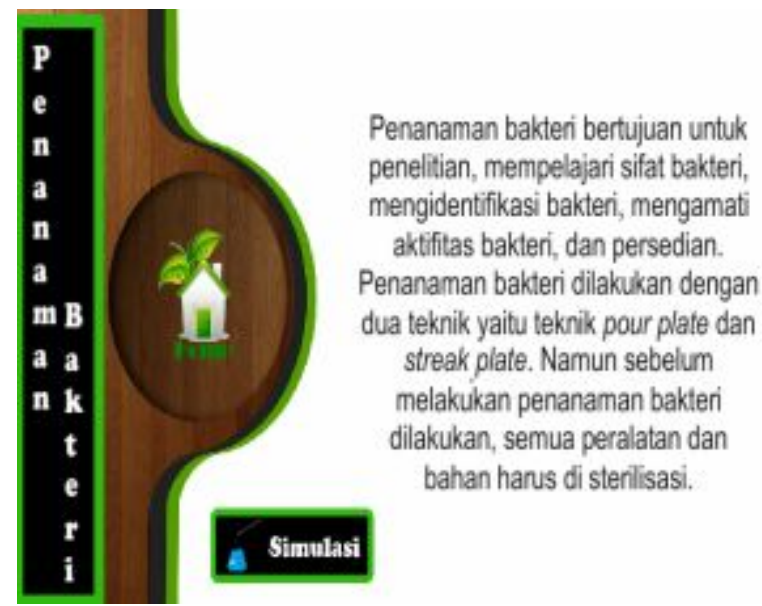

Gambar 2. Tampilan Materi Penanaman Bakteri.

3. Simulasi Praktikum Penanaman Bakteri: berisi simulasi praktikum penanaman bakteri dimulai dengan memperkenalkan alat dan bahan, selanjutnya praktikan melakukan simulasi sterilisasi alat dan bahan, dan simulasi penanaman bakteri dengan teknik pour plate dan streak plate (Gambar 3). 


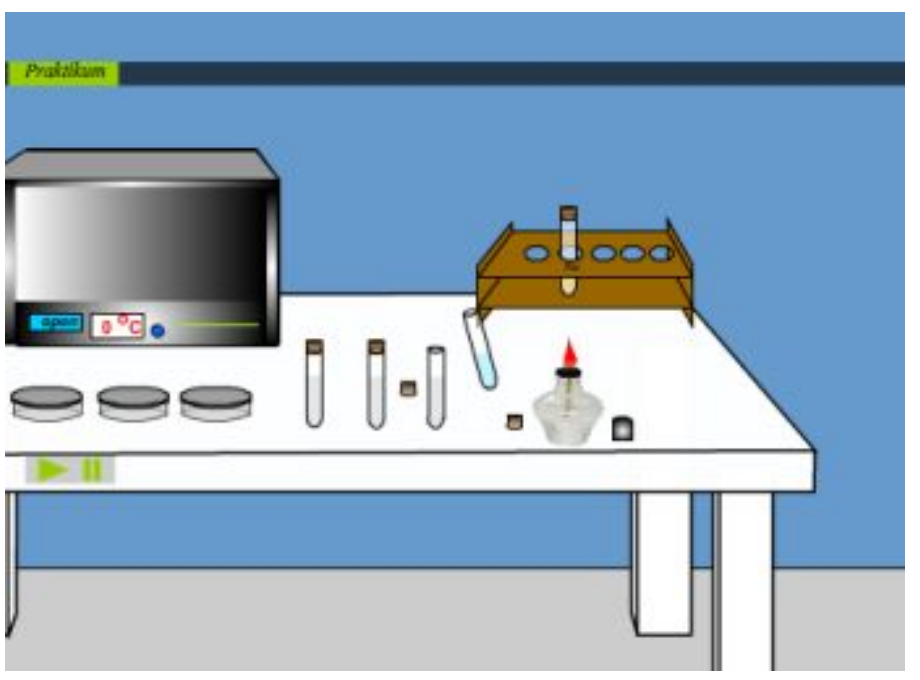

Gambar 3. Tampilan Simulasi Praktikum Penanaman Bakteri.

4. Evaluasi. Tampilan evaluasi dapat dilihat pada Gambar 4. Gambar 4 merupakan salah satu tampilan halaman evaluasi pada media virtual laboratory. Evaluasi dilakukan dengan teknik tes berbentuk objektif pilihan ganda. Jumlah soal sebanyak 10 soal tes. Evaluasi dikerjakan oleh praktikan dengan memilih option yang tersedia a,b,c, d, dan e. setelah semua soal dikerjakan maka akan diketahui skor yang diperoleh praktikan.

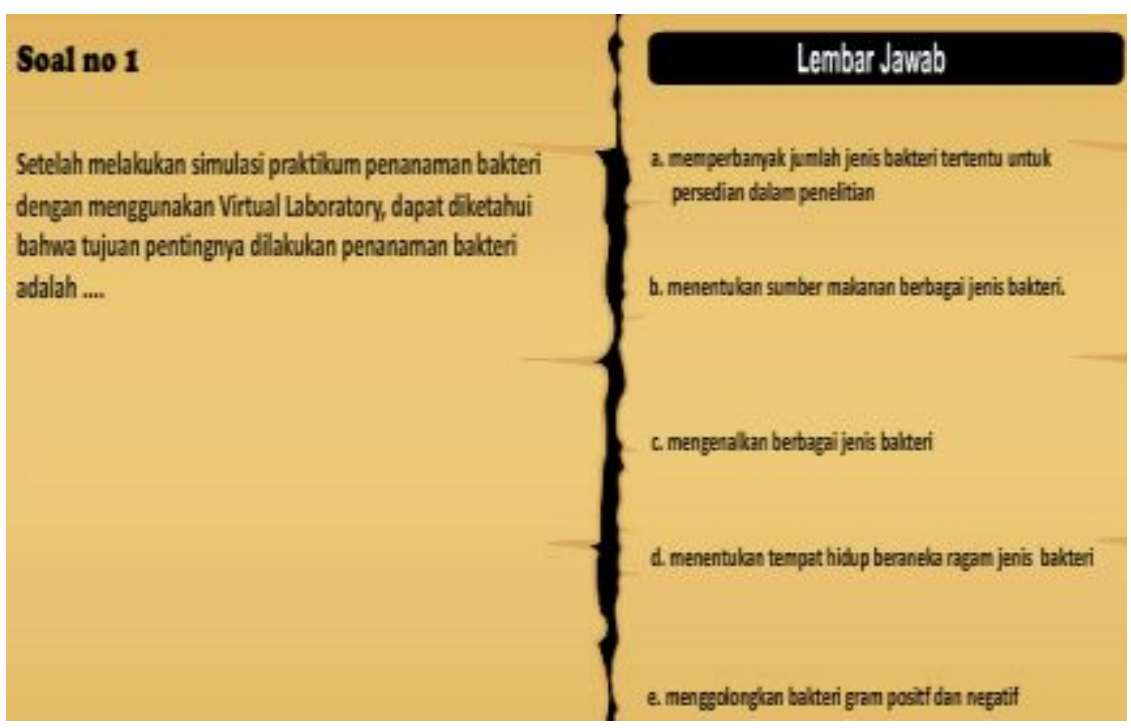

Gambar 4. Tampilan Bagian Evaluasi. 
C. Evaluasi

1. Validasi Ahli

Validasi media virtual laboratory dilakukan oleh 2 orang validator ahli. Satu orang ahli media merupakan dosen pengajar di pendidikan Matematika FKIP
Untan. Sedangkan ahli materi adalah dosen pengajar mata kuliah mikrobiologi FKIP Universitas Muhammadiyah Pontianak. Hasil validasi dari kedua ahli dapat dilihat pada Tabel 1.

Tabel 1. Rekapitulasi Hasil Validasi Virtual Labaratory.

\begin{tabular}{|c|c|c|c|c|c|}
\hline \multirow{2}{*}{ Aspek } & \multirow{2}{*}{ Kriteria } & \multicolumn{2}{|c|}{ Validator ke } & \multirow{2}{*}{$\mathbf{K i}$} & \multirow{2}{*}{$\mathbf{A} \mathbf{i}$} \\
\hline & & 1 & 2 & & \\
\hline \multirow{4}{*}{ Format } & $\begin{array}{l}\text { 1. Kesesuaian dan keterpaduan warna } \\
\text { background dan desain pada Virtual } \\
\text { Laboratory }\end{array}$ & 3 & 3 & 3 & \multirow{4}{*}{2.9} \\
\hline & $\begin{array}{llll}\text { 2. } & \begin{array}{l}\text { Kejelasan gambar pada } \\
\text { Laboratory }\end{array} & \text { Virtual } \\
\end{array}$ & 3 & 3 & 3 & \\
\hline & $\begin{array}{l}\text { 3. Kejelasan animasi pada Virtual } \\
\text { Laboratory }\end{array}$ & 2 & 4 & 3 & \\
\hline & $\begin{array}{llll}\text { 4. } & \text { Kejelasan tulisan pada Virtual } \\
\text { Laboratory }\end{array}$ & 3 & 2 & 2.5 & \\
\hline \multirow{6}{*}{ Isi } & $\begin{array}{l}\text { 5. Virtual Laboratory dapat digunakan } \\
\text { untuk mencapai tujuan pembelajaran }\end{array}$ & 2 & 4 & 3 & \multirow{6}{*}{3.1} \\
\hline & $\begin{array}{ll}\text { 6. } & \text { Konsep dalam Virtual Laboratory } \\
& \text { sesuai dengan Kompetensi Dasar (KD) }\end{array}$ & 3 & 4 & 3.5 & \\
\hline & $\begin{array}{l}\text { 7. Virtual Laboratory dapat menjelaskan } \\
\text { konsep penanaman bakteri }\end{array}$ & 2 & 4 & 3 & \\
\hline & $\begin{array}{l}\text { 8. Virtual Laboratory membantu } \\
\text { mahasiswa dalam melakukan praktikum } \\
\text { penanaman bakteri }\end{array}$ & 2 & 4 & 3 & \\
\hline & $\begin{array}{l}\text { 9. Virtual Laboratory membantu } \\
\text { mahasiswa dalam memahami sub materi } \\
\text { penanaman bakteri }\end{array}$ & 2 & 4 & 3 & \\
\hline & $\begin{array}{l}\text { I0. Informasi yang disajikan akurat dan } \\
\text { terbaru }\end{array}$ & 3 & 3 & 3 & \\
\hline \multirow[t]{2}{*}{ Bahasa } & $\begin{array}{l}\text { 11. Kosakata yang digunakan mudah } \\
\text { dipahami dan sesuai dengan tingkat } \\
\text { perkembangan usia }\end{array}$ & 3 & 3 & 3 & \multirow[b]{2}{*}{3} \\
\hline & $\begin{array}{l}\text { 12. Bahasa yang di gunakan bebas makna } \\
\text { ambigu }\end{array}$ & 3 & 3 & 3 & \\
\hline Praktis & $\begin{array}{l}\text { 13. Fasilitas pendukung dalam pemakaian } \\
\text { Virtual Laboratory dapat digunakan } \\
\text { oleh mahasiswa }\end{array}$ & 3 & 4 & 3.5 & 3.5 \\
\hline Efektif & $\begin{array}{l}\text { 14. Meningkatkan rasa ingin tahu dan minat } \\
\text { belajar mahasiswa }\end{array}$ & 3 & 4 & 3.5 & \\
\hline
\end{tabular}


Pengembangan Virtual Laboratory 64

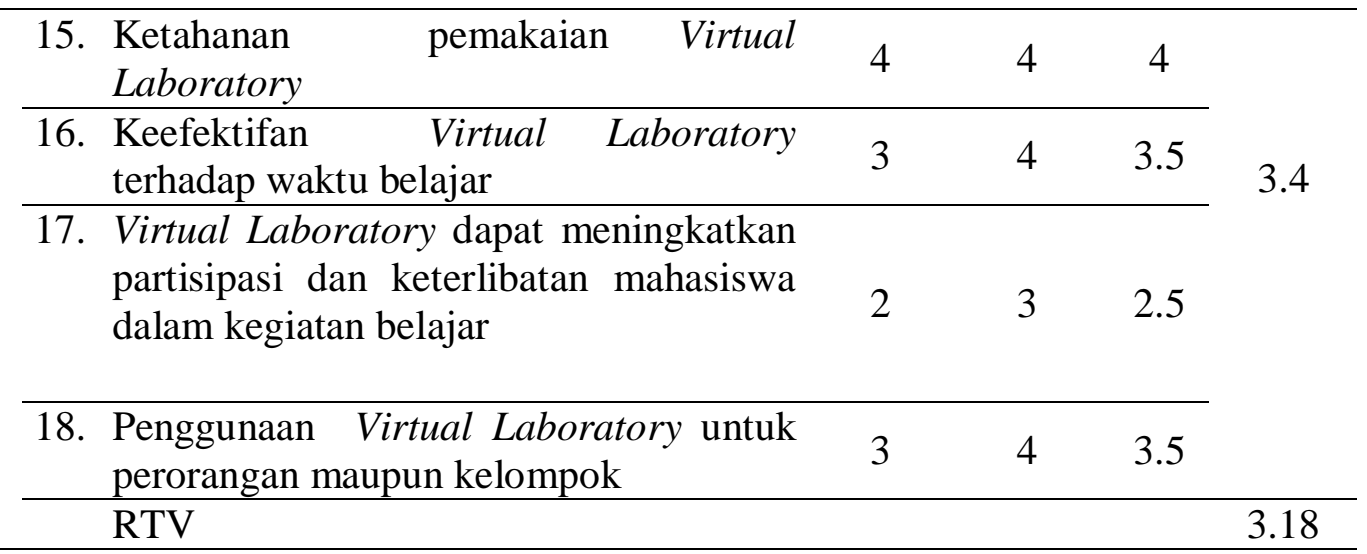

Keterangan:

\begin{tabular}{|c|c|}
\hline $\mathrm{Ki}$ & : Rata rata tiap kriteria \\
\hline $\mathrm{Ai}$ & : Rata rata tiap aspek \\
\hline $\begin{array}{l}\text { RTV } \\
\text { validasi }\end{array}$ & : Rata rata total \\
\hline Kriteria ke & alidan : \\
\hline $3 \leq \mathrm{RTV} \leq 4$ & : Valid \\
\hline $2 \leq \mathrm{RTV}<3$ & : Cukup valid \\
\hline $1 \leq \mathrm{RTV}<2$ & $\begin{array}{l}\text { : Tidak valid } \\
\text { ah dalam Yamasa }\end{array}$ \\
\hline
\end{tabular}
2010)

(Khabibah dalam Yamasari,

Revisi dilakukan pada media virtual laboratory sesuai saran dan masukan dari validator ahli media dan materi. Revisi dilakukan terutama pada bagian format dan isi.

Pengembangan media yang dilakukan dengan 4 tahapan ini, meliputi tahap analisis, desain, evaluasi dan revisi. Implementasi media (berupa prototype) di lakukan pada kelompok kecil. Berdasarkan hasil pengembangan media pada tahap evaluasi media virtual laboratory dikategorikan valid dengan rata rata total validasi (RTV) 3,18. Kategori valid tergambar dari hasil penilaian validator, dimana validator media dan materi menyatakan baik berdasarkan konten (sesuai kurikulum, dan materi) dan konstruk (sesuai dengan kaidah).
Praktis tergambar dari hasil uji coba, dimana semua mahasiswa dapat menggunakan media virtual laboratory dengan baik dan efektif. Rata rata total aspek isi, bahasa, praktis dan efektivitas dikategorikan valid dengan nilai masing masing masing 3,1 (valid); 3 (valid); 3,5 (valid) dan 3,4 (valid). Namun untuk format rata rata total aspek dikategorikan cukup valid $(2,9)$. Rata-rata total validasi media yaitu 3.18 (valid) yang berarti media virtual laboratory dapat digunakan untuk uji coba pada kelompok kecil. Validasi virtual laboratory dilakukan untuk mengetahui kelayakan atau kevalidan media terhadap pembelajaran. Validasi dilakukan oleh 2 orang validator yaitu 1 orang ahli media dan 1 orang ahli materi. Pada lembar validasi virtual laboratory terdapat 5 aspek yang digunakan untuk menguji layak atau tidak virtual laboratory digunakan, yaitu aspek format, aspek isi, bahasa, praktis dan efektif. Aspek ini dikembangkan dan dimodifikasi dari lembar validasi media Yamasari (2010).

Validator menilai virtual laboratory memiliki kelebihan 


\begin{abstract}
sebagai media yang dapat membantu mahasiswa dalam mempelajari tahapan tahapan praktikum isolasi bakteri tanpa harus melakukan praktikum secara langsung. Selain itu media ini dapat mengefektifkan waktu pembelajaran, karena simulasi dalam virtual laboratory hanya memerlukan waktu 30 menit. Hal ini sesuai dengan pendapat Asyhar (2012), kelebihan virtual laboratory, antara lain 1) tidak memerlukan peralatan laboratorium dan bahan-bahan yang harganya mahal, sehingga dapat menjadi alternatif mengatasi keterbatasan atau ketiadaan fasilitas alat dan bahan laboratorium, 2) mengurangi keterbatasan waktu, jika tidak ada cukup waktu untuk mengajari di dalam laboratorium hingga mereka paham. Sehingga efektif membantu peserta didik yang lambat dan dapat memacu efektivitas belajar bagi yang lebih cepat. Selain itu media ini dinilai bersifat interaktif, sehingga peserta didik dapat melakukan praktikum sebagaimana yang dilakukan pada laboratorium fisik dengan visual yang menarik. Peserta didik juga dapat menggunakan secara sendirisendiri atau berkelompok dan tidak mesti di ruang laboratorium.
\end{abstract}

Namun demikian, validator ahli juga menilai terdapat beberapa kelemahan pada media virtual laboratory terutama pada aspek format dan isi. Validator ahli menyarankan agar dilakukan penambahan audio untuk memperjelas proses pelaksanaan praktikum. Dalam pelaksanaan praktikum agar diberikan keterangan yang jelas tentang hal hal yang boleh dilakukan maupun yang tidak boleh dikerjakan oleh praktikan. Pemberian label dalam alat serta larutan bahan yang dibuat perlu dilakukan untuk memperjelas dalam pemilihan dan pemakaian alat dan bahan. Perlu dibuat tombol untuk mengakhiri suatu proses dalam pelaksanaan praktikum. Pada pelaksanaan sterilisasi, alat autoclave yang digunakan dianggap belum berfungsi shingga disarankan agar dapat dibuat simulasi yang lebih sesuai yang dapat mendeskripsikan bahwa alat tersebut bekerja.

\title{
2. Hasil Belajar
}

Berdasarkan hasil uji coba terbatas pada 9 orang mahasiswa dengan kategori masing- masing 3 orang mahasiswa kelompok atas, sedang, dan bawah dapat dilihat pada Tabel 2.

Tabel 2. Nilai Tes Hasil Belajar Mahasiswa.

\begin{tabular}{cccc}
\hline No & Nama & Nilai & Keterangan \\
\hline 1 & CHR & 70 & T \\
\hline 2 & USW & 60 & TT \\
\hline 3 & GIN & 80 & T \\
\hline 4 & ESK & 90 & T \\
\hline 5 & HRD & 70 & T \\
\hline 6 & IRM & 80 & T \\
\hline
\end{tabular}




\begin{tabular}{cccc}
\hline No & Nama & Nilai & Keterangan \\
\hline 7 & DES & 70 & T \\
\hline 8 & DER & 80 & T \\
\hline 9 & DEV & 80 & T \\
\hline & RATA-RATA & 75,55 & \\
\cline { 2 - 4 } & PERSENTASE & & $88,88 \%$ \\
& KETUNTASAN & & \\
\hline
\end{tabular}

Kriteria ketuntasan: nilai $\geq 70$

Persentase mahasiswa yang menjawab benar soal no 1,3 , dan 5 sebesar $100 \%$, soal no. 2 dan 8 sebesar $88,88 \%$, soal no. 4 dan 10 $55,55 \%$, soal no. 6 sebesar $44,44 \%$, soal no. 7 sebesar $100 \%$, sedangkan soal no. 9 sebesar $22,22 \%$. Kesalahan yang dijumpai paling banyak tersebut yaitu pada soal mengenai tahapan penanaman bakteri dengan teknik pour plate dan ciri medium penanaman bakteri.

Berdasarkan nilai tes hasil belajar mahasiswa diperoleh ratarata 75,55 dengan persentase ketuntasan sebesar $88,88 \%$. Hal tersebut menunjukkan berdasarkan hasil uji coba pada kelompok kecil bahwa materi penanaman bakteri yang di sampaikan dengan media virtual laboratory lebih mudah dipahami. Pemahaman mahasiswa terutama pada pengetahuan konseptual dan prosedural. Media pembelajaran virtual laboratory ini berfungsi manipulatif. Menurut Asyhar (2012), fungsi manipulatif pada media karena terkait dengan simulasi yang terdapat dalam media ini mampu menampilkan benda-benda atau situasi yang menggambarkan benda atau situasi sebenarnya. Simulasi praktikum penanaman bakteri dan evaluasi di sampaikan secara interaktif karena mahasiswa dapat terlibat langsung mengoperasikan media tersebut disesuaikan dengan kecepatan belajar mahasiswa masing-masing. Keterlibatan mahasiswa secara aktif dalam kegiatan simulasi tersebut menyebabkan mahasiswa dapat membangun pengetahuannya sendiri. Hal tersebut sejalan dengan pendapat Rousseau dalam Sardiman (2011) bahwa segala pengetahuan harus diperoleh dengan pengamatan sendiri, pengalaman sendiri, penyelidikan sendiri dengan bekerja sendiri, dengan fasilitas yang diciptakan sendiri baik secara rohani maupun teknis.

\section{Simpulan dan Saran}

Simpulan dari penelitian ini adalah sebagai berikut:

1. Pengembangan virtual laboratory berbasis multimedia interaktif pada sub materi isolasi bakteri dilakukan melalui empat tahapan : analisis, disain, evaluasi dan revisi.

2. Ditinjau dari rata rata total validasi ahli media dan materi virtual laboratory berbasis multimedia interaktif pada sub materi isolasi bakteri dinilai valid ( $\mathrm{RTV}=3,18)$.

3. Nilai rata rata pemahaman konsep mahasiswa pada sub materi isolasi bakteri yang diajarkan dengan menggunakan virtual laboratry berbasis multimedia interaktif 
adalah 75,55 dengan persentase ketuntasan sebesar $88,88 \%$.

Perlu dilakukan penelitian lanjutan untuk melakukan uji coba produk media virtual laboratory dan mengetahui efektivitasnya.

\section{Daftar Pustaka}

Asyhar, R. (2012). Kreatif Mengembangkan Media Pembelajaran. Jakarta: Referensi Jakarta.

Nurrokhmah, I. E, Sunarto, W. (2013). Pengaruh Penerapan Virtual labs Berbasis Inkuiri Terhadap Hasil Belajar Kimia. Semarang: CiE 2 (1). (Online).

(http://journal.unnes.ac.id/sju/i ndex.php/chemined. Diakses pada tanggal 10 Mei 2014).

Razi, P. (2013). Hubungan Motivasi Dengan Kerja Ilmiah Siswa Dalam Pembelajaran Fisika Menggunakan Virtual Laboratory Di Kelas X SMAN Kota Padang. Padang: Jurnal Teknologi Informasi dan Pendidikan. Vol 6 No 2. (Online). (Http://jurnal-tip.ne. Diakses tanggal 10 Mei 2014).

Rusman., Kurniawan, D dan Riyana. C. (2012). Pembelajaran Berbasis Teknologi Informasi dan Komunikasi. Jakarta: Rajawali Pers.
Santoso, H. (2009). (Tesis). Pengaruh Penggunaan Laboratorium Riil dan Laboratorium Virtuil Pada Pembelajaran Fisika Ditinjau Dari Kemampuan Berpikir Kritis Siswa. Surakarta: Program Pascasarjana Universitas Sebelas Maret surakarta 2009. (Online) (http://eprints.uns.ac.id/5203/. diakses pada tanggal 20 Januari 2014).

Sardiman A.M. 2011. Interaksi dan Motivasi Belajar mengajar. Jakarta: Raja grafindo Persada

Susanti, E., Purwoko., dan Zulkardi. 2008. Development research: Studi kasus pada Computer Aided Learning (CAL).Jurnal Pendidikan Matematika, Vol. 2. No.2

Yamasari, Y. (2010, 4 Agustus). Pengembangan Media Pembelajaran Matematika Berbasis ICT yang Berkualitas. Seminar Nasional Pascasarjana X-ITS. ISBN No. 979-545-0270-1. Surabaya.

Yuniarti, F, Dewi, P, dan Susanti, R . (2012). Pengembangan Virtual Laboratory Sebagai Media Pembelajaran Berbasis Komputer pada Materi Pembiakan Virus. UJBE. Vol. 1 No. 1, 32. 